\title{
AN OUTLINE OF THE PROGRESS IN THE CARE AND HANDLING OF THE INSANE IN THE LAST TWENTY YEARS.
}

Br C. ECGENE RIGGS, A.M., M.D.

St, Pan1, Minn.

TO

try to tell you in a brief twenty minutes of all the advances that have been made in the last twenty years in the care and handling of the insane seems to be very like one of those impossible tasks, such as emptying the river with a thimble, which the wicked fairies used to set for the heroes of the tales we read when we were children.

So much has been accomplished along this line in these last twenty crowded years, during which the pulse of the world has perhaps beat to a quicker time than erer before in human history, that to give you even the dryest, barest outline of the most important achierements would take more than the allotted time. So I shall not try so much to recount a list of accomplished facts as to outline the principles upon whose acceptance the facts of our progress have been based.

As I conceive these changes, amounting to a revolution in our way of looking at and handling the insane, they have all bren dependent upon the slowly-growing recognition of two principles: The first is that the insane man is still a man, and therefore entitled, as far as his condition aill pirmit, not only to life, but to "liberty and the pursuit of happiness"; he is an individual, and his individuality is entitled to respect. The less he is treated as something exceptional, and the more his condition and environment are approximated to

${ }^{1}$ Read before the Twentieth Aunual Session of the National Conference of Corrections and Charities. 
the conditions and surroundings of ordinary life, the better it will be for him. This view of the matter is, of course, limited by the recognition that he is a sick man, and that in so far as such treatment may be of avail, his condition demands hospital care. The second principle is that it is the duty of the State to see that the insane-all of them, perhaps, but certainly the indigent,- have this opportunity to be made whole, if possible; and, if not, to lead a life as much like a normal life as their state will permit.

The actual outcome of this second principle has been the establishment of State care or State supervision for the insane. Twenty years ago there was practically in each State two methods of caring for the insane: First, a State system, managed by State officers and responsible to the State. Second, a county system, managed by county officers and responsible to no one. The State institutions were designed for the acute insane. The cases pronounced incurable were discharged and removed from the asylums to the poor-houses of the counties from which they came, to make room for fresh cases in the asylums, which would otherwise have become choked with the accumulation of chronic cases. At that time there were abont sixty State institutions for the insane in the United States, and of this number three only were designed for the care of the chronic insane, namely: the Insane Department of the State Almshouse at Tewksbury, Mass., Willard Asylum in New York, and the Rhode Island Asylum on the State Farm at Cranston. These institutions were re. garded as being still in the experimental stage, the question of the advisability and the possibility of State care for all of the insane being still an open one. With the exception of the inmates of these three institutions, and such of the incurable class as might chance to be retained in the asylums - these were chiefly paying patients, whose friends were able to prevent their return to the counties,-the rest of the chronic insane in the United States were in county care. What that care was it is 
painful to rehearse. Everywhere, as the earlier reports of the State boards faithfully show, ignorance and parsimony had brought about a wretched and deplorable condition of things. Said the General Agent of the State Board of Pennsylvania in 1873 , reporting on the condition of the insane in almshouses:

"They are totally neglected-morally, physically and mentally. Less attention is given to them than would be gircn to the lowest animals."

It is needless to repeat the details--cells, chains, foul air, filth, nakedness--all the sickening sequele of insufficient accommodation and neglect. It is a state of things, we may thank heaven, now belonging almost entirely to the past.

Chiefly through the ventilation of these abuses by the State boards, most of which were organized from twenty to twenty-five years ago, and through the efforts made to correct them, the idea of State care made a steady growth. It was not, and is not, believed that county care for the insane can be made what humanity demands it to be. As the result of continued agitation on the subject, we can record to-day a totally different condition of affairs.

October of this year will see the army of indigent insane in the great State of New York all housed at last in the State hospitals. In Pennsylvania, while complcte State care is not yet an accomplished fact, a large reduction has been brought about in the number of county institutions caring for the insane, and the standard of care in those retaining them has been so raised that the Committee on Lunacy, while still faithfully maintaining the principlc of State eare, finds no reasonable ground of objection to the retention of ehronic insane in these institutions until other provision can be made.

There are some six or eight States in which the principle of State Care for the indigent insane is fully established, although for laek of accommodations its practice is not yet entire. There are perhaps eight other States in which the prineiple of State Care for all 
of the insane, both indigent and well to do, is the established one; but I believe the State of Minnesota is the cnly one of these whieh has as yet sueceeded in absolutely doing away with all eountry or town eare of the insane, the doors of the State Hospitals being open to all, and up to this present the aecommodations having sufficed. Several other States, however, notably Massachusetts and Wiseonsin, have suceeded in solving the problem of earing for the insane in a creditable manner, pending the complete establishment of State care, whieh is regarded ererywhere as the objective point toward which to work, steps looking in any other direction being regarded as a distinct retrogression.

This much for. the advance that has been made in the principle of State care. Now for the advances achieved in the idea of what the State ought to do for its insane wards. The average asylum of twenty years ago was a structure whose chief feature was a central corridor, with sleeping rooms opening from it upon both sides, the whole asylum being an arrangement of such corridors, either linear, square or H-shaped. Here and there the dividing wall between room and corridor was done away with, making a recess of the former, whose windows, together with the end windows, served to light the corridor. The ventilation was usually artificial. The corridors were used for sitting, reading, working, taking exercise and eating, as well as being passageways from one part of the house to another. Their furniture was ehiefly chairs and tables, these in many institutions being fastened to the floor. Few attempts were made at decoration. Anything more unattractive, gloomy and unhomelike than life upon these corridors can hardly be eonceived. They answered to nothing in the life of a human home, sueh as the patient had been aeeustomed to in the world outside. The wards were always loeked, thus adding the oppression of the feeling of elose con. finement to those whose condition was such as to permit them to be conscious of it. As eating was done on the 
wards or in ward dining-rooms, the arrival of the hour for meals created no sense of change or diversion. Exercise, when taken, was usually in airing-courts, and, in order to reduce the number of attendants required, the walls of these were frequently so high that the patients could not see over them, thus making their excursions into the outer air merely the substitution of an unroofed prison for a covered one. Disćipline was cnforced upon the wards, but employment was not enconraged. The idca prevailed that the insane were all alike and should all lead the same life. There resulted from this a deadly monotony of existence, stuch as might well drive a sane man mad. The disciplined idleness tended to make of the able-bodied patients a set of loafers; it "hospitalized" them, as the term is now used. The amount of mechanical restraint used would seem excessive to-day. This was partly clue to insufficient attendance and a false conception of the attendants' duties, and partly to a belief that there was no other way of handling disturbed cases. The attendants were "keepers." Amusements were furnished, it is true, but the patient often took but a languid interest in them, and there were long, vacant, unfilled hours. The whole atmosphere of the asylum was, in brief, prisonlike, for the idea of the institution as a prison or place of detention for those dangerous to society still held its own against the more modern idea of the asylum as a hospital for the sick.

While drawing this picture of the average asylum life of twenty years ago, I wish to call attention to the fact that there were men in charge of the insane at that time, and for years before, who upheld strongly what we are accustomed to think the modern ideas; men who advocated and carried out faithfully in the institutions under their charge the principles of hygienic employment, non-restraint, hospital care, and the like. But these men were, after all, the conspicuous and brilliant exceptions-the voices of those crying in the wilderness, "Prepare ye the way!" 
THE CARE AND HANDLING OF THE INSANE. 625

In the longer report which I have prepared for the proceedings of this body, I have endeavored to enter into detail regarding the growth of the modern ideas, and the way in which they have been carried out in different States. Here it must suffice to explain what they are, and to sketch the modern hospital as compared with the old asylum. One fundamental idea in the treatment of the insane to-day is the hospital ideathe view of the insane man which recognizes that he is a sick man, and entitled to the best of treatment for his disease while there is any probability of cure. The overcrowded condition of many of our institutions for the insane to-day frequently prevents the satisfactory carrying out of such strict hospital treatment as the alienists in charge of our asylums would be glad to give. One direction of advance in the future must necessarily be along this line.

Next is the idea that the insane man is entitled to $a$ more normal life than he was permitted to lead formerly. To the jail-like structure of twenty years ago has succeeded the cottage hospital, as illustrated at Kankakee, Toledo, Ogdensburg, and elsewhere, where the many comparatively small, separate buildings permit of a far closer classification of the insane than could be made formerly; of the complete separation of such classes as the epileptics, the dements, the uncleanly, the violently suicidal and homicidal; of a quiet retreat, with homelike surroundings, for the convalescents; of the subdivision. of the mild and inoffensive into groups of cases which shall work no injury mentally to one another. These hospitals are more elastic, more flexible; they permit, to a greater extent, of the individualization which our ideas. demand.

The number of the insane sheltered in such institutions has increased in the last twelve years from a few hundreds to over six thousand; and, as new asylums are required, they will undoubtedly be built upon this plan, or some still more flexible modification of it.

With the advance in classification and the change in 
the style of buildings erected have gone other advances. Chief among them is the recognition of the importance of furnishing employment as well as amusement to the insane: of the fact that idleness is as inwholesome for the able-bodied insane man as for the sane one. In the institutions which have made a specialty of their industrial system-sueh as Kankakee and the Alabama Insane Hospital-from serenty to eighty per cent. of the inmates are now griven employment, and in almost all asylums from thirty to fifty per cent. are occupied, groatly to their own physical and mental advantage, and also the financial advantage of the State, as they thus become, in some measure, self-supporting, Outdoor occupation is more easily provided than formerly, owing to the increased amount of land for agrieultural as well as pleasure grounds, now habitually attached to new asylums. Greater efforts for winter amusements are made, and for outdoor summer excursions. Some asylums have cottages at the seashore or in the mountains, to which parties of convalescents are sent to their great advantage.

Many improvements have taken place in asylum service. The increase in wages, and the establishment of training schools in a large number of our best asylums, in which a feature is made of mental nursing, and the attenclants are taught to take an intelligent interest in those under their care, is attracting a different class of persons to this occupation, and the idea of a keeper of a mad person is giring way to that of nurse and companion of the sick. This is one of the most notable of the minor advances achieved, as it is impossible for a physician to earry out his best plans for his insane patients without skilled and taetful attendants.

The advanee in the amount of liberty which, it has been found, may safely be permitted many classes of the insane, is great. Almost all asylums now have one or two open wards, in which the patients are free to come and go as they ehoose during the day, and this has been found not to result in an increase but in a diminution of 
attempted escapes. This also is true of the paroling of patients upon the grounds, a practice which has grown greatly. Mechanical restraint has fallen into practical disuse in perhaps half of our asylums, and in the remaincler its use is vcry greatly diminished. This, of course, has required an increase in the amount of attendance needed. The introduction in very many of our hospitals of a woman physician upon the staff has been an adrance, of whose advisability there can be no question.

The building of congregate dining-rooms or refectories, where the patients assemble for meals, and the doing away with the gloomy airing-courts, permitting the patients to take their exercise, under sufficient supervision, in the open air, have been found to be beneficial not only to halth, bitt to cliscipline.

Thus it will be seen that, with hospital care for the acute insane, with the greatly increased degree of liberty permitted, with the larger opportunities for employment and amusement, with the stricter classification prevailing, the daily life of the patient in our hospitals has become quite a different thing in the last twenty years.

The growth of the spirit of classification has shown itself not only in the sorting out of the groups best fitted to be together inside the asy-lum, but also in the separation of certain classes as totally unfitted to remain in the same institutions with the ordinary insane. It is now universally conceded that separate provision should be made for the criminal insane and for epileptics. Four States are already caring for their criminal insane in separate institutions, and Ohio and California have made provision for epileptics. New York scemed abont to do so, but the bill was unfortunately vetoed.

Apart from those changes, bearing directly upon the daily life of the insane, there have been other advances affecting their welfare.

Changes have been made in the commitment laws of many States, which generally, though not always, have looked in the direction of recognizing the primary neces- 
sity of a physician's verdict, and of assuring that that verdict shall be a competent one. The commitment laws have, in some instances, been made stricter, making admission to an asylum a more difficult matter. This has been offset in severa1 States by the enactment of statutes permitting persons in the incipient stages of insanity, who could not be legally committed, to commit themselves voluntarily for a length of time, terminable at will, for treatment in insane hospitals. Another, of similar intent, has been the establishment of "OutPatient" departments in certain hospitals, designed for the gratuitous treatment of mental disease in its earlier stages.

Provision has been made in certain States for emergency commitment. Detention hospitals have been erected in large cities, avoiding the injurious and degrading necessity of detaining the insane in jails pending commitment, but these last advances are not yet as general as they should become.

Before closing, I wish to allude to the brilliant work done by students of science and medicine in acquiring and disseminating among the profession a better knowledge of the nervous system, and to mention the work, whose goal is yet unattained, of those pathologists who are hoping to throw more light upon the brain states in the insane, and to bring to pass the day when our knowledge of these physical conditions, associated with mental alienation, will make our treatment more effective and more sure.

In this hasty enumeration of the details, in which our ideas of and our care for the insane have been revolutionized in twenty years, I have necessarily passed over many of the small things which give an added comfort to the existence of these unfortunates.

At best we cannot hope, where cure is impossible, to do more than to make them as little miserable as possible. I am far from claiming that all has been done in this direction that humanity demands; but, I trust, I have shown how fairly we are started on the road. 